\title{
Upscaling Ozone Flux in Forests from Leaf to Landscape
}

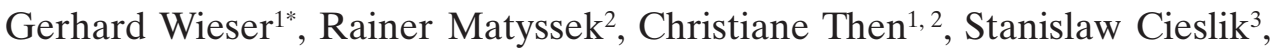 \\ Elena Paoletti ${ }^{4}$, Reinhart Ceulemans ${ }^{5}$ \\ ${ }^{1}$ Unit Alpine Timberline Ecophysiology, Federal Research and Training Centre for Forests, \\ Natural Hazards and Landscape \\ Rennweg 1, 6020 InnsbruckInnsbruck, Austria \\ ${ }^{2}$ Ecophysiology of Plants, Department of Ecology, Technische Universität München \\ Am Hochanger 13, 85354 Freising, Germany \\ ${ }^{3}$ Joint Research Centre \\ Ispra (VA), Italy \\ ${ }^{4}$ Istituto per la Protezione delle Piante (IPP) - Consiglio Nazionale delle Ricerche \\ Via Madonna del Piano 10, Sesto Fiorentino (FI), Italy \\ ${ }^{5}$ Research Group of Plant and Vegetation Ecology, Department of Biology, University of Antwerp \\ Groenenborgerlaan 171, 2020, Antwerp, Belgium
}

Received: 3 October 2007. Accepted 14 December 2007.

\begin{abstract}
Summary
Although stomatal conductance for ozone $\left(\mathrm{O}_{3}\right)$ correlates with leaf to air water vapor difference $\left(\mathrm{VPD}_{\mathrm{LA}}\right)$ at the leaf level, uncertainty in up-scaling to the whole tree level can be overcome by means of sap flow measurements at the tree trunk. Further up-scaling to the stand level is possible by relating whole tree $\mathrm{O}_{3}$ flux to silvicultural and/or tree-allometric data. In such a way, canopy conductance and $\mathrm{O}_{3}$ uptake can be related to ground surface area. When normalized, canopy conductance is demonstrated to follow a functional relationship to $\mathrm{VPD}_{\mathrm{LA}}$ across several forest ecosystems thus allowing a generalization of model approaches. Further up-scaling to the landscape level, however, needs further investigations due to differences in the response of canopy conductance to environmental drivers in forest stands and grassland ecosystems, respectively.
\end{abstract}

Key-words: Ozone uptake, trees, forest, stand, grassland, up-scaling.

\section{Introduction}

Analysis of ozone $\left(\mathrm{O}_{3}\right)$ impact on vegetation requires knowledge of site-specific $\mathrm{O}_{3}$ formation, transport, and uptake by the foliage. Crucial $\mathrm{O}_{3}$ fluxes are non stomatal deposition, including deposition on external surfaces (soil, bark and leaf), reactions with air volatiles (Cieslik, 2004), and, in particular, stomatal deposition, i.e. absorption or uptake through the stomata into the leaf mesophyll (Wieser, 2002; Matyssek et al., 2007).

Foliage is the primary site of $\mathrm{O}_{3}$ uptake (Wittmann et al., 2007), as stomata represent the interface of this uptake with the atmosphere. Assessment of $\mathrm{O}_{3}$ uptake by plants is important because only the amount of $\mathrm{O}_{3}$ absorbed through the stomata into the leaf mesophyll represents the "phytomedically" relevant $\mathrm{O}_{3}$ dose, which may affect molecular/biochemical, (eco-) physiological and, eventually, growth processes (Matyssek and Sandermann, 2003; Wieser and Tausz, 2006; Wieser and Matyssek, 2007; Matyssek et al., 2007). Duyzer et al. (1995) and Munger et al. (1996) demonstrated $\mathrm{O}_{3}$ deposition in forest ecosystems to relate to stomatal conductance, indicating the stomatal pathway to govern $\mathrm{O}_{3}$ uptake also at the stand level (Bortier et al., 2000). The degree of stomatal opening, however, is controlled by physiological processes, predominantly imposed by irradiance, evaporative demand of the atmosphere and soil water availability (Wieser, 2002; Matyssek et al., 
2004; Nunn et al., 2005; Löw et al., 2006). In total, the apparent $\mathrm{O}_{3}$ uptake of stands is determined, apart from stomatal regulation, by the foliage area at a specific site, as expressed, e.g., by the leaf area index (LAI; Nunn et al., 2007).

Given the dependence of $\mathrm{O}_{3}$ risk of vegetation on the amount of $\mathrm{O}_{3}$ taken up by the foliage it is the aim of this paper to examine recent progress in up-scaling $\mathrm{O}_{3}$ uptake from the leaf to the stand and landscape level, respectively.

\section{Scaling from the leaf to the tree and stand levels}

The traditional focus of plant ecophysiology, i.e. understanding how plants cope with often stressful habitats (incl. exposure to $\mathrm{O}_{3}$ ), is organism centred. Predicting and analysing the structure and function of ecological systems on larger spatial and temporal scales are research challenges of high importance, but of great difficulty. Estimating $\mathrm{O}_{3}$ flux via the stomata into intact leaves by gas exchange measurements (section 2a.) is the primary stage for further upscaling to the tree, stand and landscape level. Then we will bring in the use of the sap flow technique as a tool for up-scaling to the whole tree and the stand level. We will also focus on the combination of the eddy covariance technique with the sap flow approach for validating non-stomatal $\mathrm{O}_{3}$ deposition (section 2b). Finally, possible differences in the $\mathrm{O}_{3}$ flux between forests and grassland ecosystems will be highlighted (section 2c).

\subsection{Assessment of ozone uptake at the leaf level}

The stomatal $\mathrm{O}_{3}$ flux as a proportion to the total flux into stands (Wang et al., 1995; Winner, 1994) can quantitatively be related to the leaf level and derived from cuvette or fumigation chamber studies, using a mass-balance approach (Havranek and Wieser, 1989, 1994; Skärby et al., 1987; Wang et al., 1995). Total $\mathrm{O}_{3}$ flux is calculated from the difference between the $\mathrm{O}_{3}$ concentration at chamber inlet and outlet, as multiplied by the air flow rate. As this approach provides $\mathrm{O}_{3}$ deposition both on leaves and chamber walls, $\mathrm{O}_{3}$ fumigations with empty chambers need to be operated as a control to assess the chamber sink strength for $\mathrm{O}_{3}$ deposi- tion (Matyssek et al., 1995; Wieser, 2002). Still, by adopting this approach, the stomatal $\mathrm{O}_{3}$ influx cannot be distinguished from the non-stomatal $\mathrm{O}_{3}$ deposition at the leaf level, unless measurements are also carried out after stomatal closure (Grulke et al., 2007).

The stomatal $\mathrm{O}_{3}$ influx is typically derived from leaf-level gas exchange measurements, employing the water vapour surrogate method (e.g. Matyssek et al., 1995). This method makes use of stomatal conductance for water vapour $\left(\mathrm{G}_{\mathrm{H} 2 \mathrm{O}}\right)$, which is calculated from the leaf transpiration rate and the gradient of vapour pressure inside the intercellular spaces to that of the ambient air surrounding the leaf. Once $\mathrm{G}_{\mathrm{H} 2 \mathrm{O}}$ is known, stomatal $\mathrm{O}_{3}$ flux into the leaf mesophyll results as:

$$
\mathrm{FO}_{3}=\left(\mathrm{O}_{\mathrm{a}}-\mathrm{O}_{\mathrm{i}}\right) * \mathrm{G}_{\mathrm{O} 3},
$$

upon exchanging, in stomatal conductance, the diffusion coefficient of water vapour (cf. Cowan, 1977; Nobel, 1983) against that of ozone (i.e. $\mathrm{G}_{\mathrm{O} 3}=\mathrm{G}_{\mathrm{H} 2 \mathrm{O}} * 0.613$; Laisk et al., 1989). $\mathrm{FO}_{3}$ is the flux or uptake rate of $\mathrm{O}_{3}$ into the leaves; $\mathrm{O}_{a}$ and $\mathrm{O}_{\mathrm{i}}$ are the mole fractions of ozone in air outside the leaf and within the leaf-intercellular space, respectively. As $\mathrm{O}_{\mathrm{i}}$ approaches nil in the leaf-intercellular space (Laisk et al., 1989; Moldau et al., 1990), given the rapid decomposition of $\mathrm{O}_{3}$ into oxidative derivatives in the intercellular air space and apoplast (cf. low mesophyll resistance to $\mathrm{O}_{3}$, Runeckles, 1992), $\mathrm{FO}_{3}$ is governed by $\mathrm{G}_{\mathrm{O} 3}$ and $\mathrm{O}_{2}$. Passage of $\mathrm{O}_{3}$ across the cuticle is negligible, as the cuticle's high diffusion resistance to $\mathrm{O}_{3}$ is high relative to that of open stomata (Kerstiens and Lendzian, 1989).

In general, $\mathrm{O}_{3}$ uptake derived from gas exchange measurement is in good agreement with assessments based on the chamber inlet/outlet approach of differential $\mathrm{O}_{3}$ concentrations (see above), as shown for Fagus sylvatica in figure 1. Similar results were obtained for Larix decidua (Wieser, 2002), Picea abies (Dobson et al., 1990; Polle et al., 1995; Wieser and Havranek, 1993) and Populus spp. (Wang et al., 1995). However, $\mathrm{O}_{3}$ uptake rates based on the chamber approach tend to be higher than those derived from leaflevel gas exchange, in Figure 1 by about 0.8 $\mathrm{nmol} \mathrm{m} \mathrm{m}^{-2} \mathrm{~s}^{-1}$. This difference is attributable to non-stomatal $\mathrm{O}_{3}$ deposition on external leaf and 


\section{Fagus sylvatica}

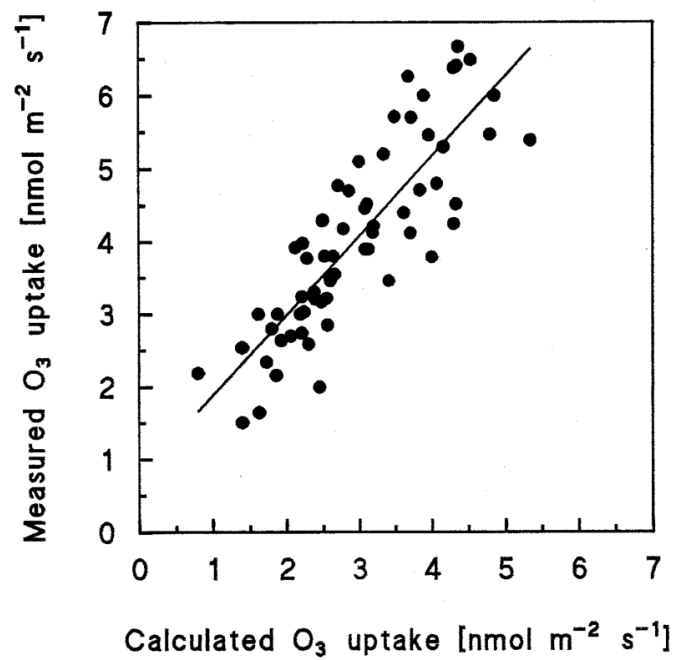

Figure 1. Correlation between calculated and measured ozone uptake rates in leaves of Fagus sylvatica. Each point represents a daily mean value taken from 65 diurnal courses of shoot gas exchange measured continuously during the growing season 2004 at Kranzberg Forest. The points were fitted by the linear regression: $y=1.096 \mathrm{x}+0.78 ; \mathrm{r}^{2}=0.71$; $\mathrm{p}<0.001$.

twig surfaces, which cannot be resolved by the chamber approach (see above). Conversely, boundary layers are destroyed by leaf-level gas exchange assessments, which typically affect $\mathrm{O}_{3}$ uptake (Wieser et al., 2003), tending to overestimate stomatal $\mathrm{O}_{3}$ deposition. Nevertheless, as at the leaf level the influence of environmental factors on stomatal aperture, and hence also on $\mathrm{FO}_{3}$, became evident (Fig. 2; Wieser and Havranek, 1993, 1995; Wieser et al., 2000), this approach provided the basis for modelling $\mathrm{O}_{3}$ flux as a tool in risk assessment (e.g. Emberson et al., 2000; Tuovinen et al., 2007). Such models, however, need a species- and site-specific parameterisation, especially with respect to maximum stomatal conductance, evaporative demand and soil water availability (Wieser and Emberson, 2004; Nunn et al., 2005)

\subsection{Upscaling $\mathrm{o}_{3}$ flux from trees to forest stands}

Since transpiration and $\mathrm{O}_{3}$ flux into the foliage are coupled through stomatal regulation, sap flow techniques (cf. Cermak et al., 1973; Sakuratani, 1981; Granier et al., 1985) that determine crown transpiration can be used to assess stomatal $\mathrm{O}_{3}$ flux at the tree level (Wieser et al., 2003;

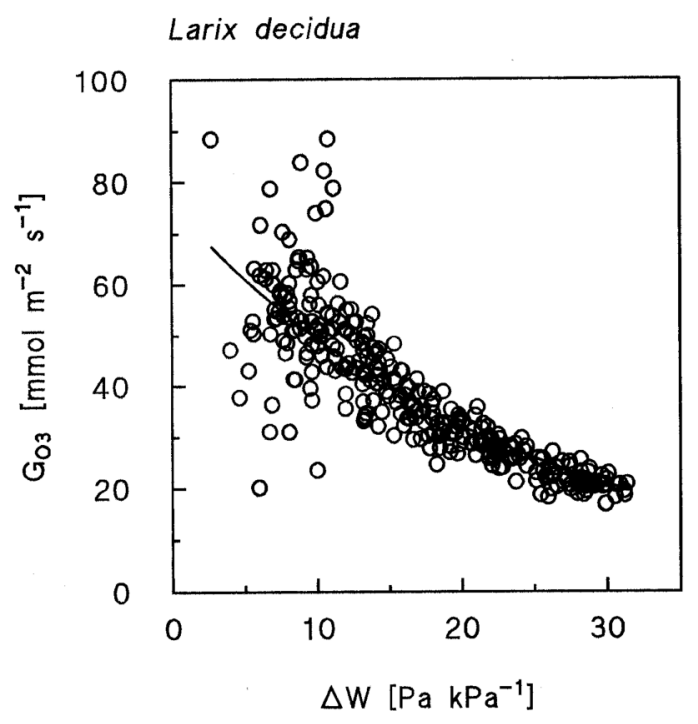

Figure 2. Stomatal conductance for ozone $\left(\mathrm{G}_{\mathrm{O} 3}\right)$ of Larix decidua needles in relation to leaf to air vapour pressure difference $(\Delta \mathrm{w})$. Data are half hour means obtained at Mt. Patscherkofel (1950 m a.s.l.) at a photosynthetic photon flux density $<600 \mu \mathrm{mol} \mathrm{m} \mathrm{s}^{-2} \mathrm{~s}^{-1}$. Points were fit by exponential regression: $\mathrm{y}=79 * \exp (-0.045 \mathrm{x}) ; \mathrm{r}^{2}=0.71$ (Wieser unpublished).

Matyssek et al., 2004; Nunn et al., 2007). Wholetree $\mathrm{O}_{3}$ uptake rates combined with stand density data (cf. Cermak et al., 2004) so that stomatal stand-level $\mathrm{O}_{3}$ uptake can be expressed per unit of ground area (Wieser et al., 2006a; Matyssek et al., 2007). As an example, the seasonal course of environmental parameters, daily mean canopy conductance for $\mathrm{O}_{3}$ and $\mathrm{FO}_{3}$ of a subalpine Pinus cembra forest are shown in figure 3. Cumulative $\mathrm{O}_{3}$ uptake (COU) during the growing season was $140 \mathrm{mmol} \mathrm{m}^{-2}$ ground area, which corresponds to COU of $13.8 \mathrm{mmol}$ $\mathrm{m}^{-2}$ on a total needle surface area basis (leaf area index, LAI, $10.1 \mathrm{~m}^{2}$ total surface area per $\mathrm{m}^{2}$ ground surface area). As only minor boundary layer effects prevailed under the opencanopy conditions of this timberline forest, the leaf-level COU is in good agreement with that of $14 \mathrm{mmol} \mathrm{m}^{-2}$ obtained in the same forest at the needle level by the cuvette technique (Wieser et al., 2000). Quantitative clarification, however, is needed for closed-canopy forest conditions. Nevertheless, as $\mathrm{COU}_{\text {leaf }}=\mathrm{COU}_{\text {stand }}$ /LAI, data as shown in figure 3 will enable the validation of models which are currently used in risk assessment, where $\mathrm{COU}_{\text {leaf }}=$ cumulative 


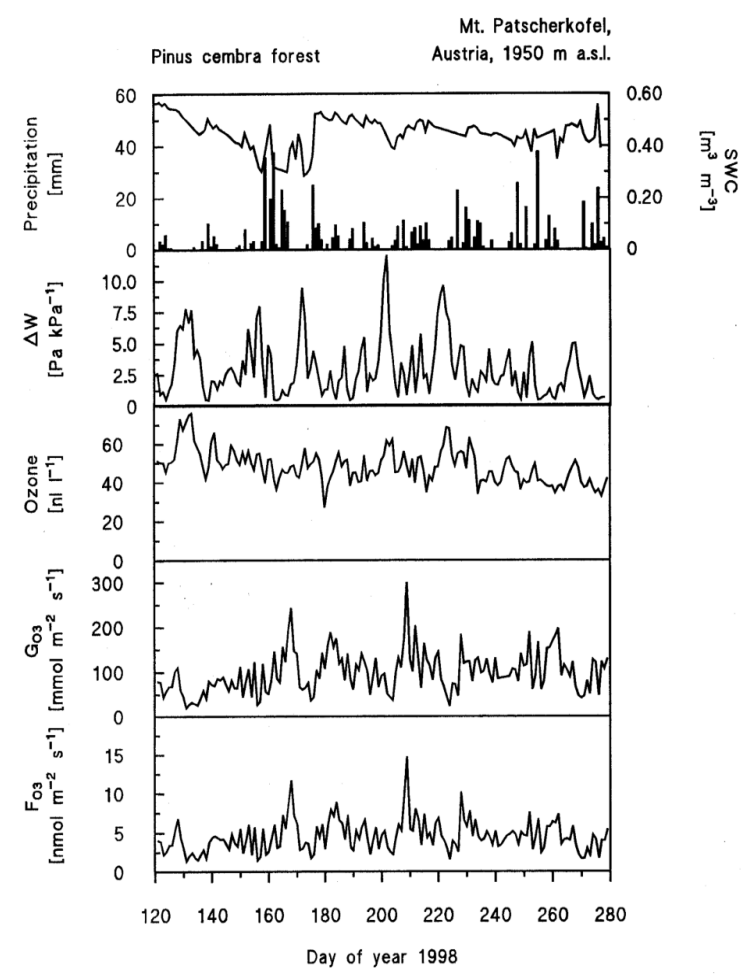

Figure 3. Time course of daily sum of precipitation, daily mean soil water content (SWC), mean leaf to air vapour pressure difference $(\Delta \mathrm{w})$, mean ambient ozone concentration $\left[\mathrm{O}_{3}\right]$, ground-area scaled daily mean canopy conductance for ozone $\left[\mathrm{G}_{\mathrm{O} 3}\right]$, and ground-area scaled daily ozone uptake rate $\left[\mathrm{F}_{\mathrm{O} 3}\right]$ in a subalpine Pinus cembra forest (stand density 1038 trees ha ${ }^{-1}$, stand basal area $47.6 \mathrm{~m}^{2} \mathrm{ha}^{-1}$, LAI $10.1 \mathrm{~m}^{2}$ total surface area per $\mathrm{m}^{2}$ ground surface area) during 28 April through 6 October 1998 (Wieser unpublished).

ozone uptake at the leaf level and $\mathrm{COU}_{\text {stand }}=$ cumulative ozone uptake at the stand level

The acceptance of sap-flow derived wholetree $\mathrm{O}_{3}$ uptake for risk assessment on a routine basis will depend on model applications, which should preferably not become too complex for practical use (Matyssek et al., 2007; Emberson et al., 2000). One step towards simplification is the finding, that the dependence of canopy conductance $\left(G_{C}\right)$ on leaf to air vapour pressure difference $\left(\mathrm{VPD}_{\mathrm{LA}}\right)$ obeys a similar relationship across a wide range of contrasting tree species and site conditions (Nunn et al., 2007; cf. also Schulze and Hall, 1982) and even entire forest stands (Fig. 4). Furthermore, normalizing the relationship between canopy conductance and $\mathrm{VPD}_{\mathrm{LA}}$ by setting $\mathrm{G}_{\mathrm{c}}$ in each stand to $100 \%$ at a $\mathrm{VPD}_{\mathrm{LA}}$ of $10 \mathrm{~Pa} \mathrm{kPa}^{-1}$ allows to derive one

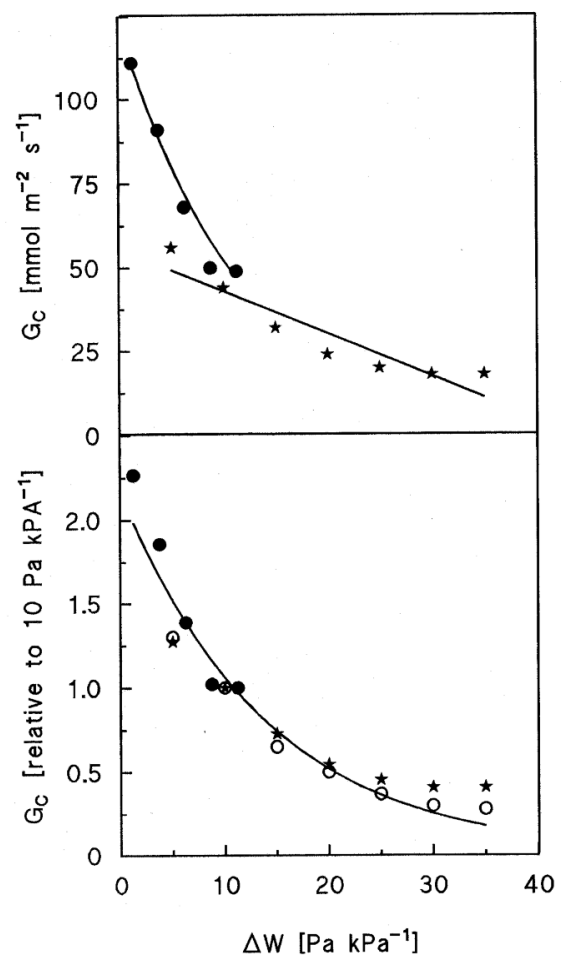

Figure 4. Absolute and relative canopy conductance of a $\mathrm{Pi}$ nus cembra forest (-) at Mt. Patscherkofel, south of Innsbruck, Austria (1950 m a.s.l.), a Pinus canariensis ( $\star$ ) forest in the Mountains of La Victoria, Tenerife (1650 $\mathrm{m}$ a.s.1.), and Populus tremuloides $(\mathrm{O})$ forest in Prince Albert National Park, central Saskatchewan, Canada in relation to leaf to air vapour pressure difference $(\Delta \mathrm{w})$. Relative data were fit by the mono-exponential equation $\mathrm{y}=2.19 * \exp (-0.073 \mathrm{x}) ; \mathrm{r}^{2}$ $=0.94$. Redrawn after data from Wieser et al., 2006b ( $P$. cembra and P. canariensis), and Hogg and Hurdle, 1997 (P. tremuloides).

common underlying, exponential function (Fig. 4) also obtained at the entire tree (Nunn et al., 2007) and the leaf level (Wieser, 2002).

The sapflow-based $\mathrm{O}_{3}$ flux assessment may be combined with eddy covariance techniques (Duyzer et al., 1995; Mikkelsen et al., 2000; Zeller and Nikolov, 2000). These latter techniques in combination with measuring profiles of $\mathrm{O}_{3}$ levels in stands inherently assess the total $\mathrm{O}_{3}$ flux, i.e. the sum of stomatal and nonstomatal $\mathrm{O}_{3}$ deposition at the stand level (Zeller and Nikolov, 2000). Then, the resistance analogy is used to calculate stomatal $\mathrm{O}_{3}$ fluxes (Cieslik, 2004). In addition, when combining eddy covariance and sapflow approaches (the latter upon upscaling stomatal $\mathrm{O}_{3}$ flux to the stand level, see above), the non-stomatal $\mathrm{O}_{3}$ deposition at the stand level, which is crucial for validating 


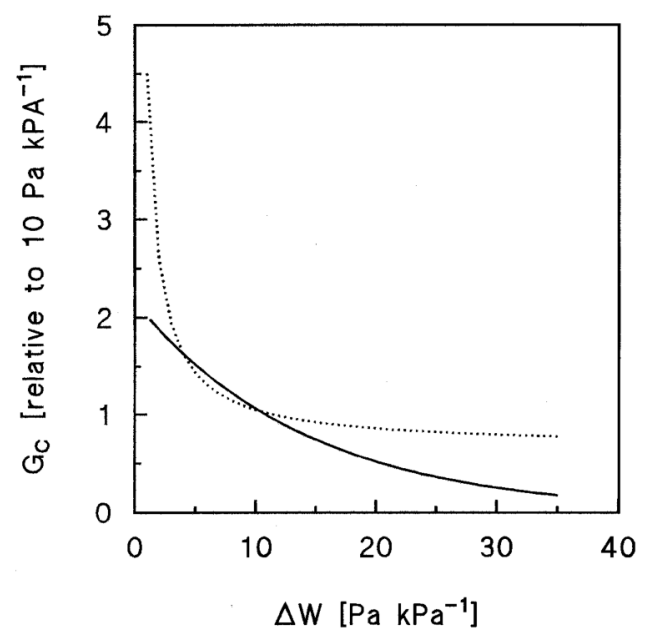

Figure 5. Relative conductance of forests (solid line; from Fig. 4) and grasslands (dotted line; after data from Wieser 1983 ) in relation to leaf to air vapour pressure difference $(\Delta \mathrm{w})$.

current flux-based $\mathrm{O}_{3}$ risk models, can be derived empirically as the difference between the respective outcomes of the two approaches.

\subsection{From forests to lanscape}

The eddy covariance technique (Wohlfahrt, 2004; Hammerle et al., 2007) as well as weighing lysimeters (Wieser, 1983; Scott et al., 2002) can also be used for short or annual vegetations, such as grassland ecosystems, to assess stand-level transpiration and hence derive canopy conductance and $\mathrm{FO}_{3}$. However, as depicted in figure 5, forests and grasslands may differ in their dependence of $\mathrm{G}_{\mathrm{c}}$ on $\mathrm{VPD}_{\mathrm{LA}}$. Such differences may be attributed to contrasting canopy structure and roughness of tall forests versus low-stature grasslands, and hence, coupling of transpiration with the atmosphere. In addition, differences in leaf mass ratio (LMR) (forests having more unfavourable LMR than grasslands) may also influence uptake and loss of water, and hence, stomatal response in particular to $\mathrm{VPD}_{\mathrm{LA}}$ (Fig. 5) and soil water availability. Therefore, differential uptake characteristics of ozone are likely to exist in forests and grasslands, although this issue still demands for clarification.

\section{Conclusions}

The sap-flow based estimation of $\mathrm{O}_{3}$ flux represents a novel tool for estimating the actual $\mathrm{O}_{3}$ dose taken up by the foliage of entire trees and forest stands under actual site conditions. In addition, common underlying relationships between $G_{c}$ and environmental parameters may foster plain, process-based model development of $\mathrm{O}_{3}$ uptake with respect to risk assessment in forests and grassland ecosystems. Furthermore, such data can be used for the parameterisation and the validation of $\mathrm{O}_{3}$ uptake models (Wieser and Emberson, 2004; Deckmyn et al., 2007). However, further research is needed to clarify the differences in the response of $\mathrm{G}_{\mathrm{c}}$ to environmental factors between forests and grasslands in order to merge $\mathrm{O}_{3}$ flux measurements in forest, semi-natural and crop ecosystems as at the landscape level each of these vegetation types has to be integrated into one common modelling approach.

\section{Acknowledgements}

Part of this research was supported by the EU project CASIROZ "The Carbon Sink Strength of Beech in a Changing Environment: Experimental Risk Assessment of Mitigation by Chronic Ozone Impact" (EVK2-200200165).

\section{References}

Bortier K., Ceulemans R., De Temmerman L. 2000. Effects of tropospheric ozone on woody plants. In: S.B. Agrawal and M. Agrawal (eds.): Environmental Pollution and Plant Responses, Chapter 9, 153-182. Lewis Publishers, Boca Raton \& London.

Cermak J., Deml M., Panka M. 1973. A new method of sap flow determination in trees. Biologia Plantarum, 15:171-178.

Cermak J., Kucera J., Nadezhdina N. 2004. Sap flow measurements with some thermodynamic methods, flow integration within trees and scaling up from sample tree to entire forests. Trees, 18:529-546.

Cieslik S.A. 2004. Ozone uptake by various surface types: a comparison between dose and exposure. Atmospheric Environment, 38:2409-2420.

Cowan I.R. 1977. Stomatal behavior and environment. Advances in Botanical Research, 4:117-128.

Deckmyn G., Op de Beeck M., Löw M., Then C., Verbeeck H., Wipfler P., Ceulemans R. 2007. Modelling ozone effects on adult beech trees through simulation of defence, damage, and repair costs: implementation of the CASIROZ ozone model in the ANAFORE forest model. Plant Biology, 9:320-330.

Dobson M.C., Taylor G., Freer-Smith P.H. 1990. The control of ozone uptake by Picea abies (L.) Karst. and 
P. sitchensis (Bong.) Carr. during drought and interacting effects on shoot water relations. New Phytologist, 116:465-474.

Duyzer J., Westrate H., Walton S. 1995. Exchange of ozone and nitrogen oxides between the atmosphere and coniferous forest. Water Air Soil Pollution, 85:2065-2070.

Emberson L., Ashmore M.R., Cambridge H.M., Simpson D., Tuovinen J.-P. 2000. Modelling stomatal flux across Europe. Environmental. Pollution, 109:403-413.

Granier A. 1985. Une novelle method pour la mesure du flux de seve brute dans le tronc des arbres. Annales des Sciences Forestieres, 42:193-200.

Grulke N.E., Paoletti E., Heath R.L. 2007, Comparison of calculated and measured foliar $\mathrm{O}_{3}$ flux in crop and forest species. Environmental Pollution, 146:640-647.

Hammerle A., Haslwanter A., Schmitt M., Bahn M., Tappeiner U., Cernusca A., Wohlfahrt G. 2007. Eddy covariance measurements of carbon dioxide, latent and sensible energy fluxes above a meadow on a mountain slope. Boundary-Layer Meteorology, 122: 397-416.

Havranek W.M., Wieser G. 1989. Research design to measure ozone uptake and its effects on gas-exchange of spruce in the field. In: Payer H.D., Pfirrmann T., Mathy P. (eds.): Environmental research with plants in closed chambers. Air Pollution Research Report, 26, 148-152. Commission of the European Communities, Brussels.

Havranek W.M., Wieser G. 1994. Design and testing of twig chambers for ozone fumigation and gas exchange measurements in mature trees. Proc. Roy. Soc. Edinburgh, Sect. B, 102:541-546.

Hogg E.H., Hurdle P.A. 1997. Sap flow in trembling aspen: implications for stomatal response to vapour pressure deficit. Tree Physiology, 17:501-509.

Kerstiens G., Lendzian K.J. 1989. Interactions between ozone and plant cuticles. I. Ozone deposition and permeability. New Phytologist, 112:13-19.

Laisk A., Kull O., Moldau H. 1989. Ozone concentration in leaf intercellular air spaces is close to zero. Plant Physiology, 90:1163-1167.

Löw M., Herbinger K., Nunn A.J., Häberle K.-H., Heerdt C., Werner H. Wipfler P., Pretzsch H., Tausz M., Matyssek R. 2006. Extraordinary drought of 2003 overrules ozone impact on adult beech trees (Fagus sylvatica). Trees, 20:539-548.

Matyssek R., Sandermann H.Jr. 2003. Impact of ozone on trees: an ecophysiological perspective. Progress in Botany 64, 349-404. Springer Verlag, Heidelberg.

Matyssek R., Reich P.B., Oren R., Winner W.E. 1995. Response mechanisms of conifers to air pollution. In: Smith, W.K., Hinckley, T.M. (eds.): Ecophysiology of Coniferous Forests, 255_308. Academic Press, New York.

Matyssek R., Wieser G., Nunn A.J., Kozovits A.R., Reiter I.M., Heerdt C., Winkler J.B., Baumgarten M.,
Häberle K.-H., Grams T.E.E., Werner H., Fabian P., Havranek W.M. 2004. Comparison between AOT40 and ozone uptake in forest trees of different species, age and site conditions. Atmospheric Environment, 38:2271-2281.

Matyssek R., Bytnerowicz A., Karlsson P.-E., Paoletti E., Sanz M., Schaub M., Wieser G. 2007. Promoting the O3 flux concept for forest trees. Environmental Pollution, 146:587-607.

Mikkelsen T.N., Ro-Poulsen H., Pilegraad K., Hovmand M.F., Jensen N.O., Christensen C.S., Hummelshoej P. 2000. Ozone uptake by an evergreen forest canopy: temporal variation and possible mechanisms. Environmental Pollution, 109:423-429.

Moldau H., Sober J., Sober A. 1990. Differential sensitivity of stomata and mesophyll to sudden exposure of bean shoots to ozone. Photosynthetica, 24:446-458.

Munger J.W., Wofsy S.C., Bakwin P.S., Fan S., Goulden M.L., Daube B.C., Goldstein A.H., Moore K., Fitzjarrald D. 1996. Atmospheric deposition of reactive nitrogen oxides and ozone in a temperate deciduous forest and a sub-arctic woodland. 1. Measurements and mechanisms. Journal of Geophysical Research, 101:12639-12657.

Nobel P.S. 1983. Biochemical Plant Physiology and Ecology. Freeman and Co., New York.

Nunn A.J., Kozovits A.R., Reiter I.M., Heerdt C., Leuchner M., Lütz C., Liu X., Winkler J.B., Grams T.E.E., Häberle K.H., Werner H., Fabian P., Rennenberg H., Matyssek R. 2005. Comparison of ozone uptake and responsiveness between a phytotron study with young and a field experiment with adult beech (Fagus sylvatica). Environmental Pollution, 137:494-506.

Nunn A.J., Wieser G., Metzger U., Löw M., Wipfler P., Häberle K.-H., Matyssek R. 2007. Exemplyfying whole-plant ozone uptake in adult forest trees of contrasting species and site conditions. Environmental Pollution, 146:629-639.

Polle A., Wieser G., Havranek W.M. 1995. Quantification of ozone influx and apoplastic ascorbate content in needles of Norway spruce trees (Picea abies L., Karst) at high altitude. Plant Cell Environment, 18:681-688.

Runeckles V.C. 1992. Uptake of ozone by vegetation. In: Lefohn A.S. (ed.): Surface level ozone exposures and their effects on vegetation, 157-188. Lewis Publishers Inc., Chelsea, Mi. (USA).

Sakuratani T. 1981. A heat balance method for measuring water flux in the stem of intact plants. Journal of Agricultural Meteorology., 37:9-17.

Schulze E.D., Hall A.E. 1982. Stomatal responses, water loss, and nutrient relations in contrasting environments. In: Lange O.L., Nobel P.S., Osmond C.B., Ziegler H. (eds.): Encyclopedia of Plant Ecology 12B, Physiological Plant Ecology II, 182-230. Springer, Berlin-Heidelberg-New York.

Scott D., Bayfield N.G., Cernusca A., Elston D.A. 2002. Use of a weighing lysimeter system to assess the effects of trampling on evapotranspiration of montane 
plant communities. Canadian Journal of Botany, 80:675-683.

Skärby L., Troeng E., Bostrom C.A. 1987. Ozone uptake and effects on transpiration, net photosynthesis, and dark respiration in Scots pine. Forest Sciences, 33:801-808.

Tuovinen J.P., Simpson D., Emberson L., Ashmore M., Gerosa G. 2007 Robustness of modelled ozone exposures and doses. Environmental Pollution, 146:578-586.

Wang D., Hinckley T.M., Cumming A.B., Braatne J. 1995. A comparison of measured and models ozone uptake into plant leaves. Environmental Pollution, $89: 247-254$.

Wieser G. 1983. Bodenwassserhaushalt alpiner Ökosysteme. Ph.D. thesis, Botany, Innsbruck University.

Wieser G. 2002. Exchange of trace gases at the tree-atmosphere interface: ozone. In: Gasche R., Papen H., Rennenberg H. (eds.): Trace Gas Exchange in Forest Ecosystems, 211-226. Kluwer Academic Publishers.

Wieser G., Emberson L. 2004. Evaluation of the stomatal conductance formulation in the EMEP ozone deposition model for Picea abies. Atmospheric Environment, 38:2339-2348.

Wieser G., Havranek W.M. 1993. Ozone uptake in the sun and shade crown of spruce: quantifying the physiological effects of ozone exposure. Trees, 7:227-232.

Wieser G., Havranek W.M. 1995 Environmental control of ozone uptake in Larix decidua Mill.: a comparison between different altitudes. Tree Physiology, 15:253-258.

Wieser G., Matyssek R. 2007. Linking ozone uptake and defense towards a mechanistic risk assessment for forest trees. New Phytologist, 174:7-9.

Wieser G., Tausz M. 2006. Proceedings on the workshop: Critical levels of ozone: further applying and developing the flux-based concept. Federal Research and Training Centre for Forests, Natural Hazards and Landscape (BFW), Wien.
Wieser G., Häsler R., Götz B., Koch W., Havranek W.M. 2000. Role of climate, crown position, tree age and altitude in calculated ozone flux into needles of Picea abies and Pinus cembra: a synthesis. Environmental Pollution, 109:415-422.

Wieser G., Luis V.C., Cuevas E. 2006a. Quantification of ozone uptake at the stand level in a Pinus canariensis forest in Tenerife, Canary Islands: an approach based on of sap flow measurements. Environmental Pollution, 140:383-386.

Wieser G., Jimenez M.S., Morales D., Luis V.C. 2006b. Quantification of canopy transpiration in two pine forests of contrasting environments. In: Morales D., Jimenez M.S. (eds.): El aguaen las plantas:desede genes y moleculas a comunidades y ecosystemas. Association VIII Symposium Rlaciones Hidricas en las Plantas, 181-184.

Wieser G., Matyssek R., Köstner B., Oberhuber W. 2003. Quantifying ozone uptake at the canopy level of spruce, pine and larch trees at the alpine timberline: an approach based on sap flow measurements. Environmental Pollution, 126:5-8.

Winner W.E. 1994. Mechanistic analysis of plant response to air pollution. Ecol. Appl., 4:651-661.

Wittmann C., Matyssek R., Pfanz H., Humar M. 2007. Effects of ozone impact on the gas exchange and chlorophyll fluorescence of juvenile birch stems ( $B e$ tula pendula Roth.). Environmental Pollution, doi:10.1016/j.envpol.2007.01.013.

Wohlfahrt G. 2004. Modelling fluxes and scalar concentrations of $\mathrm{CO}_{2}, \mathrm{H}_{2} \mathrm{O}$ and sensible heat within and above a mountain meadow canopy: a comparison of three Lagrangian models and three parameterisation options for the Lagrangian time scale. BoundaryLayer Meteorol., 113:43-80.

Zeller K.F., Nikolov N.T. 2000. Quantifying simultaneous fluxes of ozone, carbon dioxide and water vapour above a subalpine forest ecosystem. Environmental Pollution, 107:1-20. 